\title{
Synthesis and characterisation of two new bicyclic oxazolidines and investigation of their optoelectronic properties using density functional theory
}

\author{
Ghulam Abbas ${ }^{1}$, Ahmad Irfan ${ }^{2,3 *}$, Shahid Hameed ${ }^{4}$, Abdullah G. Al-Sehemi ${ }^{2,3}$, Ruifa Jin ${ }^{5}$ and \\ Shanshan Tang ${ }^{6}$ \\ ${ }^{I}$ Institut für Anorganische Chemie, Karlsruhe Institute of Technology, Engesserstrasse 15, D-76131 Karlsruhe, Germany. \\ ${ }^{2}$ Research Center for Advanced Materials Science (RCAMS), King Khalid University, Abha 61413, P.O. Box 9004, Saudi Arabia. \\ ${ }^{3}$ Department of Chemistry, Faculty of Science, King Khalid University, Abha 61413, P.O. Box 9004, Saudi Arabia. \\ ${ }^{4}$ Department of Chemistry, Quaid-i-Azam University Islamabad-45320, Pakistan. \\ ${ }^{5}$ College of Chemistry and Chemical Engineering, Chifeng University, Chifeng 024000, China \\ ${ }^{6}$ College of Life Science, Jilin Agriculture University, China.
}

\begin{abstract}
This paper presents a facile synthetic route to synthesise two new bicyclic oxazolidine compounds 3,5-bis(4chlorophenyl)-7a-methyldihydro- $1 \mathrm{H}-[1,3]$ oxazolo[3,4-c] [1,3] oxazole (1) and 3,5-bis(2-methoxyphenyl)-7a-methyldihydro$1 \mathrm{H}-[1,3]$ oxazolo[3,4-c][1,3]oxazole (2). The condensation reaction between 2-amino-2-methylpropane-1, 3-diol $\left(\operatorname{ampdH}{ }_{2}\right)$ and choloro- and methoxy- substituted aromatic aldehyde yielded the heterocyclic bicyclic compounds (1) and (2), respectively. The compounds are characterised by FT-IR and ${ }^{1} \mathrm{HNMR}$ spectroscopy and structures are conclusively determined by single crystal X-ray diffraction analysis. The ground state geometries are optimised by using density functional theory (DFT) at B3LYP/6-31G ${ }^{* *}$ level of theory to compare the geometric parameters (bond lengths, bond angles and torsion angles) with the X-ray crystallographic data. The computed geometric parameters are in good agreement with the experimental data. To shed light on the electronic and photophysical properties, DFT/B3LYP/6-31G** and time dependent DFT have been applied, respectively. Intra-molecular charge transfer has been observed in both the compounds. The absorption wavelengths are calculated with and without the solvent (acetone, acetonitrile, dimethylformamide, dimethyl sulfoxide and methanol) at TD-B3LYP/6-31G** level of theory.
\end{abstract}

Keywords: Density functional theory, optoelectronic properties, synthesis, time dependent density functional theory.

\section{INTRODUCTION}

Heterocyclic compounds have attained immense interest due to their wide range of applications in modifiers, additives, cosmetics, plastics and antioxidants (Martins et al., 2009). The cyclic compounds containing carbon, hydrogen and heteroatoms have exhibited diverse physical, chemical and biological properties (Martins et al., 2008). Oxazolidine is a class of cyclic compounds, which has displayed wide range of biological properties such as antibacterial, antitumor and antimicrobial activities (Sriharsha \& Shashikanth, 2006). These compounds are employed extensively as curing agents for resins (Swedo \& Green, 2004), synthetic intermediates (Huguenot \& Brigaud, 2006), chiral auxiliaries, and precursors for synthetically and pharmaceutically important amino alcohols present in natural products (Kim et al., 2003). Oxazolidines are synthesised by several routes, however, the most direct route is the condensation of aminoalcohol and aldehyde or ketones forming mono oxazolidines (Kang et al., 2005). The synthesis of bicyclic bisoxazolidines has been the least explored area to date (Saiz et al., 2011). 2-amino-2-methylpropane-1,3diol $\left(\mathrm{ampdH}_{2}\right)$ is a versatile compound possessing three

*Corresponding author (irfaahmad@gmail.com; (D) https://orcid.org/0000-0001-6941-6934) 
nucleophiles, which is considered as a suitable substrate for cycloaddition reactions giving five membered saturated heterocyclic compounds (Peera \& TomLinson, 2015). Two equivalents of the same aldehyde are used in both steps to form heterocyclic compounds (Bergmann, 1953). Previously, we reported $\mathrm{ampdH}_{2}$ as a ligand to synthesise tetranuclear lanthanide coordination complexes exhibiting single molecule magnet (SMM) behaviour (Abbas et al., 2012).

Herein, we report the synthesis of new bicyclic oxazolidines obtained by the reaction of ampdH $\mathrm{H}_{2}$ with p-chloro-benzaldehyde and o-methoxy benzaldehyde. The structures of resulting compounds were elucidated by spectroscopic techniques as well as single crystal $\mathrm{X}$-ray diffraction. The ground state geometers were optimised using density functional theory (DFT) at B3LYP/6-31G** level of theory to compare the geometric parameters (bond lengths, bond angles and torsion angles) with the $\mathrm{X}$-ray crystallographic data.

\section{METHODOLOGY}

All chemicals and reagents were purchased from Acros, Germany with $98 \%$ purity and used without further purification. The elemental analyses $(\mathrm{C}, \mathrm{H}, \mathrm{N})$ were performed using an Elementar Vario EL analyser. FT-IR $(450-4000 \mathrm{~cm})$ spectra were recorded on a Thermonicolet 6700, USA FT-IR spectrometer. ${ }^{1} \mathrm{HNMR}$ spectra were recorded on a Bruker Avance $300 \mathrm{MHz}$ spectrometer and calibrated to residual solvent peaks. The electronic spectra were recorded on Labomed UVD2300 UV/ Vis spectrophotometer. Single crystal XRD data were collected on an Oxford-Diffraction diffractometer, equipped with a charge - coupled device (CCD) area detector and a graphite monochromator utilising MoK- $\alpha$ radiation $(\lambda=0.71073 \AA)$.

\section{Synthesis of 3,5-bis(4-chlorophenyl)-7a- methyldihydro-1H-[1,3] oxazolo[3,4-c][1,3] oxazole (1)}

To a well stirred solution of chlorobenzaldehyde ( $2 \mathrm{mmol}$ in $10 \mathrm{~mL}$ absolute ethanol) a solution of 2-amino-2methyl-1,3-propandiol (1 $\mathrm{mmol}$ in $10 \mathrm{~mL}$ ethanol) was added and refluxed for $3 \mathrm{~h}$. The resulting mixture was cooled at room temperature and kept undisturbed. Colourless needle like crystals of compound (1) separated out overnight. Yield $87 \%$ : Anal. Calc. for $\mathrm{C}_{18} \mathrm{H}_{17} \mathrm{Cl}_{2} \mathrm{NO}_{2}$ : C, $61.72 \mathrm{H}, 4.89 \mathrm{~N}, 3.99$ found: C, $61.67 \mathrm{H}, 4.81 \mathrm{~N}, 3.87$. FT-IR $\left(\mathrm{KBr} \mathrm{cm}{ }^{-1}\right) 2954(\mathrm{C}-\mathrm{H}), 3097$ (C-H str), 1489 $(\mathrm{C}=\mathrm{C}), 1375(\mathrm{C}-\mathrm{H}), 1142(\mathrm{C}-\mathrm{N}), 1074$ (C-O). ${ }^{1} \mathrm{H}$ NMR $\left(300 \mathrm{MHz}, \mathrm{CDCl}_{3}\right): \delta$ 7.33-7.27 $(2 \mathrm{H}, \mathrm{m}), 7.26-7.18(4 \mathrm{H}$, m), 7.13-7.08 (2H, m), $5.58(1 \mathrm{H}, \mathrm{s}), 5.18(1 \mathrm{H}, \mathrm{s}), 4.10$
$(1 \mathrm{H}, \mathrm{d}), 3.88(1 \mathrm{H}, \mathrm{d}), 3.85(1 \mathrm{H}, \mathrm{d}), 3.65(1 \mathrm{H}, \mathrm{d}), 1.45$ $(3 \mathrm{H}, \mathrm{s})$.

Synthesis of 3,5-bis(2-methoxyphenyl)-7amethyldihydro-1H-[1,3] oxazolo $[3,4-\mathrm{c}][1,3]$ oxazole $(2)$

To a well stirred solution of methoxybenzaldehyde (2 mmol in $10 \mathrm{~mL}$ absolute ethanol) a solution of 2-amino-2-methyl-1,3-propandiol $(1 \mathrm{mmol}$ in $10 \mathrm{~mL}$ ethanol) was added and refluxed for $3 \mathrm{~h}$. The resulting mixture was cooled and kept overnight. Colourless needle like crystals of compound (2) separated out. Yield $85 \%$ : Anal. Calc. for $\mathrm{C}_{20} \mathrm{H}_{23} \mathrm{NO}_{4}$ : C, $70.36 \mathrm{H}, 6.79 \mathrm{~N}$, 4.10 found: C, $70.25 \mathrm{H}, 6.68 \mathrm{~N}, 4.03$. FT-IR $\left(\mathrm{KBr} \mathrm{cm}^{-1}\right)$ 2970 (C-H), 3095 (C-H str), 1489 (C=C), $1158(\mathrm{C}-\mathrm{N})$, $1080(\mathrm{C}-\mathrm{O}){ }^{1} \mathrm{H}$ NMR $\left(300 \mathrm{MHz}, \mathrm{CDCl}_{3}\right): \delta 7.78-7.68$ $(3 \mathrm{H}, \mathrm{m}), 7.18-7.10(2 \mathrm{H}, \mathrm{m}), 6.99-6.83(3 \mathrm{H}, \mathrm{m}), 5.70(1 \mathrm{H}$, s), $5.69(1 \mathrm{H}, \mathrm{s}), 4.08(1 \mathrm{H}, \mathrm{d}), 3.86(1 \mathrm{H}, \mathrm{d}), 3.84(1 \mathrm{H}, \mathrm{d})$, $3.62(1 \mathrm{H}, \mathrm{d}), 3.48(3 \mathrm{H}, \mathrm{s}), 3.34(3 \mathrm{H}, \mathrm{s}), 1.55(3 \mathrm{H}, \mathrm{s})$.

Colourless needles of compound (1) suitable for analysis by X-ray diffraction (XRD) were obtained. All the measurements were performed using Mo-K $\alpha$ radiation $(\lambda=0.71073 \AA)$ at $100 \mathrm{~K}$. Compound (1) crystallised in orthorhombic crystal system with space group $\mathrm{Pbca}$, and the cell parameters were; $\mathrm{a}=6.0577$ (7) $\AA, \mathrm{b}=20.850$ (2) $\AA, \mathrm{c}=25.272$ (2) $\AA, \mathrm{V}=3191.9$ (6) $\AA^{3}, \mathrm{Z}=8$, crystal density $=1.458 \mathrm{mg} \mathrm{m}^{-3}$, and absorption coefficient $\mu=0.42 \mathrm{~mm}^{-1}$. A total of 12362 reflections were measured $\left(\theta_{\max }=25.0\right),\left(\mathrm{R}_{\text {int }}=0.109\right)$ with 1839 reflections with $I>2 \sigma(I)$. The structure was solved by direct methods using SIR92 (Cascarano et al., 1994) and refined on $\mathrm{F}^{2}$ using full-matrix least squares using SHELXL97 (Sheldrick, 1997). The final $\mathrm{R}$ indices of $R^{1}=0.059$ and $w R^{2}=0.156$ were obtained.

Compound (2) crystallised as monoclinic colourless needles with space group $P 2 / c$. All the measurements were performed using Mo-K $\alpha$ radiation $(\lambda=0.71073 \AA)$ at $100 \mathrm{~K}$. Crystal cell parameters were; $\mathrm{a}=11.2388$ (7) $\AA, \mathrm{b}=9.8455$ (7) $\AA, \mathrm{c}=15.5764$ (10) $\AA, \mathrm{V}=1716.4$ (2) $\AA^{3}, Z=4$, crystal density $=1.321 \mathrm{mgm}^{-3}$, and absorption coefficient $\mu=0.09 \mathrm{~mm}^{-1}$. A total of 7595 reflections were measured $\left(\theta_{\max }=25.0\right),\left(\mathrm{R}_{\text {int }}=0.027\right)$ with 2678 reflections with $I>2 \sigma(I)$.

\section{Computational details}

Among density functional theory (DFT) functionals B3LYP is a good choice, which provides the best description of the geometries (Gruhn et al., 2002; Sánchez-Carrera et al., 2006; Irfan et al., 2017a; b). In the present study, the ground state $\left(\mathrm{S}_{0}\right)$ geometries were optimised by DFT/B3LYP (Lee et al., 1988; Miehlich 
et al., 1989; Becke, 1993) and 6-31G** basis set (Petersson et al., 1988). The frequency calculations were performed at the same level of theory. No imaginary frequency was noticed, which reveal that the optimised structures were reliable for further investigations. To compute the absorption wavelengths $\left(\lambda_{\mathrm{a}}\right)$, time dependent DFT was applied which has been proved as an efficient and accurate approach (Matthews et al., 1996; Irfan, 2013; 2014; Irfan et al., 2016). All the calculations were performed using Gaussian16 package (Frisch, 2016).

\section{RESULTS AND DISCUSSION}

Different synthetic strategies are opted to design bis oxazolidine compounds, which lead to obtain the target molecules using the same aldehyde in two steps. The important feature was to use the same carbonyl group in both steps of the synthesis as reported by Crab et al. (1973). Bicyclic oxazolidines were obtained by reaction of ampdH $\mathrm{H}_{2}$ with p-chloro-benzaldehyde and o-methoxy benzaldehyde. The cyclisation was carried out at elevated temperatures. Two equivalents of each aldehyde were used to obtain desired products. The stepwise synthesis of compounds (1) and (2) using $\mathrm{ampdH}_{2}$ is given in Figure 1. The reactions were performed under thermodynamic control and monitored through thin layer

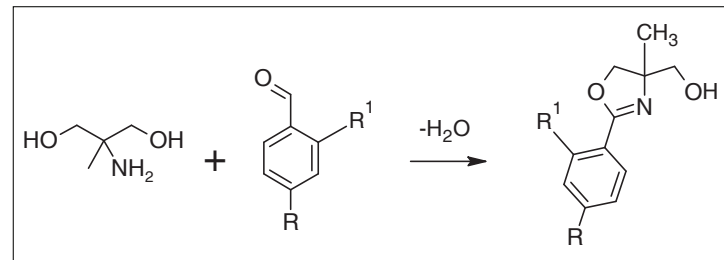

oxazoline ring

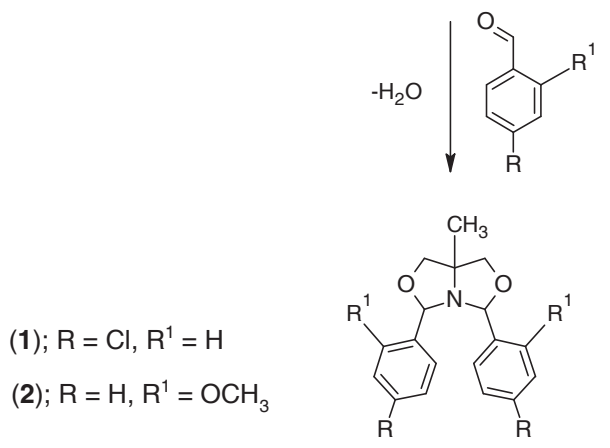

bicyclic oxazolidine ring

Figure 1: Reaction scheme for the synthesis of compounds (1) and (2) chromatography (TLC). Both compounds were isolated as crystalline products in a single solvent; e.g. ethanol giving good yield and purity.

\section{Crystal structures analysis}

The crystal structure of compounds (1) and (2) were solved and refined in orthorhombic and monoclinic crystal systems with space group $P$ bca and $P 2_{1} / \mathrm{c}$, respectively. The crystal XRD data and refinement parameters of both compounds are given in Table 1 for better comparison.

The Oak Ridge thermal ellipsoid plot (ORTEP) view for compounds (1) and (2) are shown in Figure 2, while crystal structure unit cells are shown in Figure 3. The XRD analysis reveals that for compound (1), the centroids of two oxazoline rings (facing one another) are at a distance of $1.77 \AA$, whereas for compound (2) the distance between the centres of two oxazoline rings is $1.73 \AA$ (Figure S1 - supplementary information). Bond lengths for compounds (1) and (2) are given in Tables 2 and 3 , respectively.

\section{Geometries}

The geometrical parameters, bond lengths, bond angles, dihedral angles as well as dipole moments are presented in Table 4. The optimised geometrical parameters are in good agreement with the crystal structure parameters (atom numbering scheme, Figure S2 - supplementary information). By substituting the methoxy groups at phenyl rings, we observed the major change in N1-C7 bond length of compound (2), which shortened by $0.019 \AA$; the $\mathrm{C} 7-\mathrm{N} 1-\mathrm{C} 14$ bond angle decreases by $3.25^{\circ}$ and torsion angles C4-C7-N1-C14/C4-C7-O2-C15 increases/decreases $33.27 / 72.07^{\circ}$ compared to compound (1). The trend to increase the dipole moment was observed in the following order: compound (2) < compound (1). In compound (2), a smaller dipole moment was observed, which has the methoxy groups at phenyl rings. It was found that the introduction of the $\mathrm{Cl}$ groups at phenyl rings would boost up the dipole moment.

\section{Electronic properties}

Figure 4 illustrates the distribution pattern of the frontier molecular orbitals; highest occupied molecular orbitals (HOMOs) and lowest unoccupied molecular orbitals (LUMOs). In compounds (1) and (2), HOMO density is distributed on the phenyl ring and $\mathrm{N}$ atom of the central core while LUMO is distributed on both end phenyl rings. Most of the charge is transferred from central core 
and $\mathrm{N}$ atom to phenyl moieties in compound (1), while in compound (2), charge is transferred from phenyl to phenyl moiety. Intra-molecular charge transfer (ICT) has been observed in both systems. The $\mathrm{E}_{\text {gap }}$ of these compounds were calculated at the B3LYP/6-31G** level of theory. The substitution of methoxy at phenyl ring increases the HOMOs and LUMOs energies compared to the $\mathrm{Cl}$ substituted derivative.

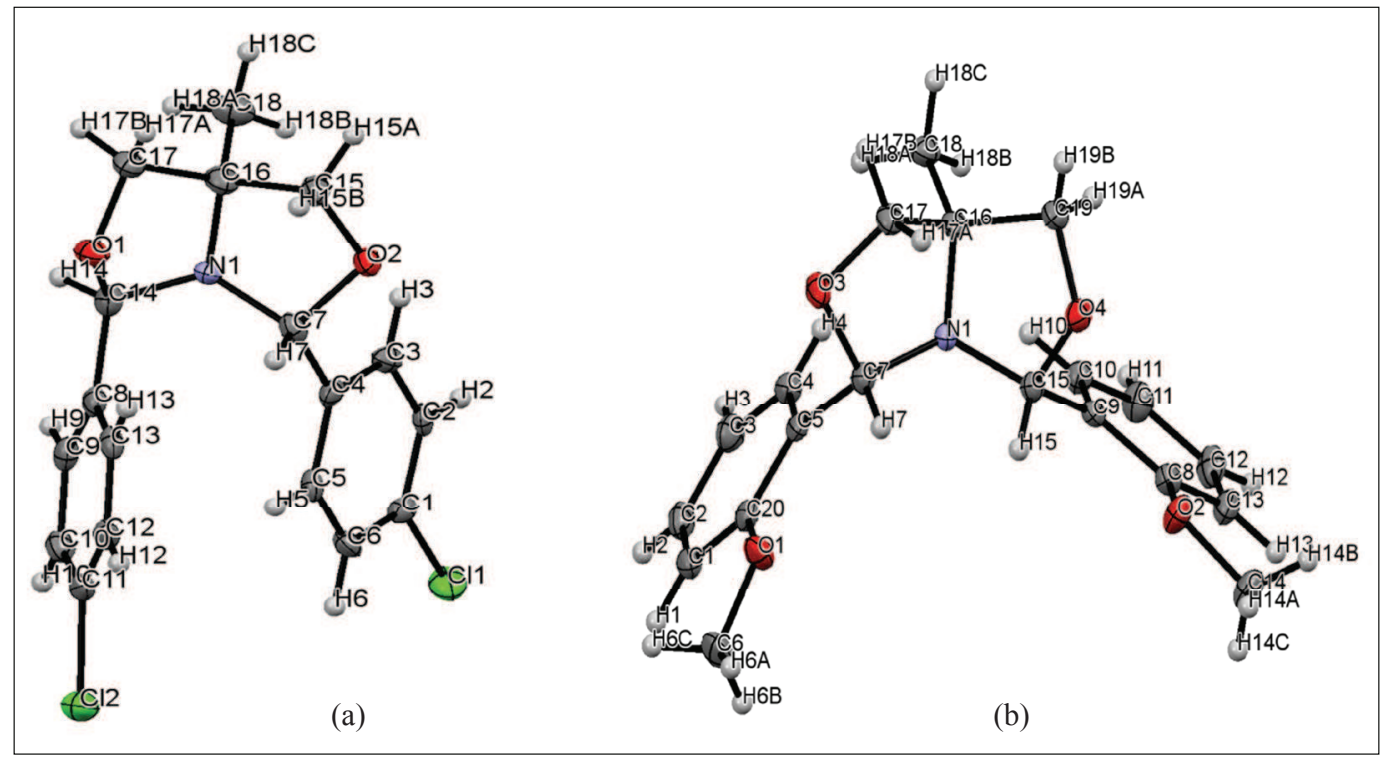

Figure 2: ORTEP plot of (a) compound (1) and (b) compound (2). Thermal ellipsoids are drawn at $50 \%$ probability level

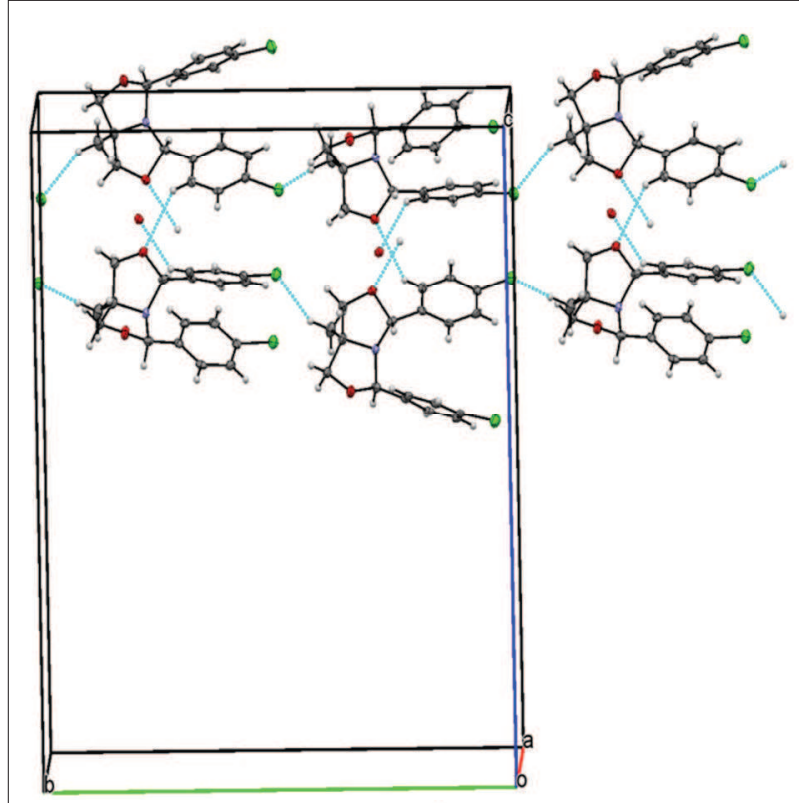

(a)

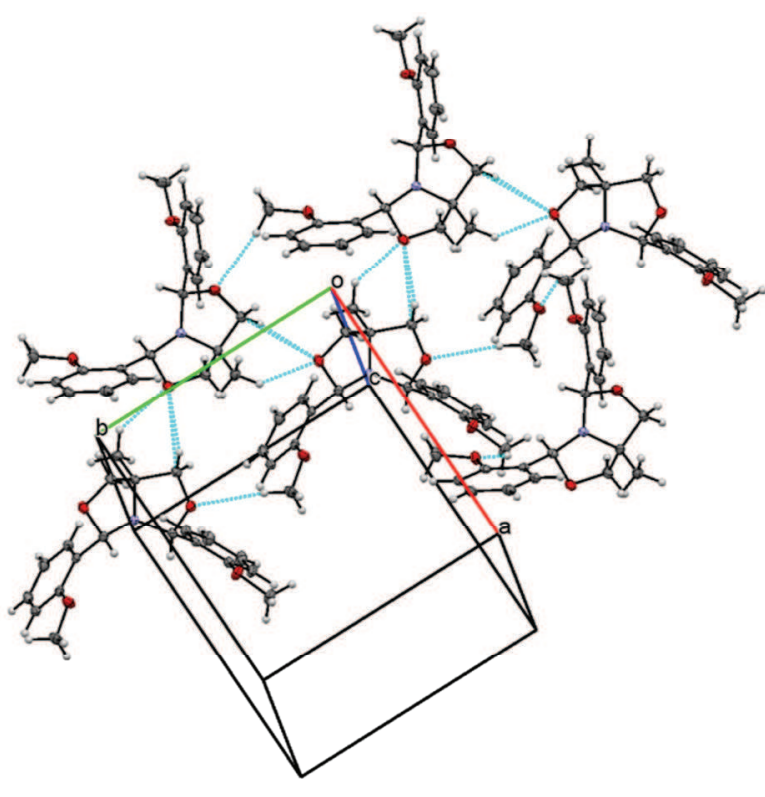

(b)

Figure 3: Crystal packing diagrams of (a) compound (1) and (b) compound (2). Hydrogen bond contacts are indicated with cyan dotted lines 
Table 1: Summary of data collection and refinement parameters for compounds (1) and (2)

\begin{tabular}{|c|c|c|}
\hline Compound & Compound (1) & Compound (2) \\
\hline Formula & $\mathrm{C}_{18} \mathrm{H}_{17} \mathrm{Cl}_{2} \mathrm{NO}_{2}$ & $\mathrm{C}_{20} \mathrm{H}_{23} \mathrm{NO}_{4}$ \\
\hline Formula weight & 350.23 & 341.39 \\
\hline Crystal size (mm) & $0.15 \times 0.03 \times 0.02$ & $0.13 \times 0.06 \times 0.02$ \\
\hline Crystal system & Orthorhombic & Monoclinic \\
\hline Space group & $\mathrm{Pbca}$ & $P 2_{I} / c$ \\
\hline$a[\AA]$ & $6.0577(7) \AA$ & $11.2388(7) \AA$ \\
\hline$b[\AA]$ & $20.850(2) \AA$ & 9.8455 (7) $\AA$ \\
\hline$c[\AA]$ & $25.272(2) \AA$ & $15.5764(10) \AA$ \\
\hline$V\left[\AA^{3}\right]$ & $3191.9(6)$ & $1716.4(2)$ \\
\hline$Z$ & 8 & 4 \\
\hline Density (Dx $\mathrm{Mg} \mathrm{m}^{-3}$ ) & 1.458 & 1.321 \\
\hline$F(000)$ & 1456 & 728 \\
\hline$T[\mathrm{~K}]$ & 100 & 100 \\
\hline$\mu\left[\mathrm{mm}^{-1}\right]$ & 0.42 & 0.09 \\
\hline$\theta$ range $\left[{ }^{\circ}\right]$ & $3.6-25.6$ & $3.0-29.5$ \\
\hline$h$ & $-7 \rightarrow 7$ & $-10 \rightarrow 13$ \\
\hline$k$ & $-24 \rightarrow 22$ & $-11 \rightarrow 11$ \\
\hline$l$ & $-28 \rightarrow 30$ & $-18 \rightarrow 18$ \\
\hline Measured reflections & 12362 & 7595 \\
\hline Independent reflections & 2803 & 3015 \\
\hline$R_{\text {int }}$ & 0.109 & 0.027 \\
\hline Parameters & 216 & 234 \\
\hline$S$ & 1.02 & 1.07 \\
\hline Reflections with $I>2 \sigma(I)$ & 1839 & 2678 \\
\hline$R\left[F^{2}>2 \sigma\left(F^{2}\right)\right]$ & 0.059 & 0.040 \\
\hline$w R\left(F^{2}\right)$ & 0.156 & 0.102 \\
\hline
\end{tabular}

Table 2: Bond lengths for compound (1) in $(\AA)$

\begin{tabular}{lccc}
\hline Parameters & Bond lengths & Parameters & Bond lengths \\
\hline $\mathrm{O} 1-\mathrm{C} 14$ & 1.432 & $\mathrm{C} 4-\mathrm{C} 7$ & 1.506 \\
$\mathrm{O} 2-\mathrm{C} 15$ & 1.423 & $\mathrm{C} 5-\mathrm{C} 6$ & 1.381 \\
$\mathrm{O} 2-\mathrm{C} 7$ & 1.425 & $\mathrm{C} 8-\mathrm{C} 9$ & 1.381 \\
$\mathrm{C} 11-\mathrm{C} 1$ & 1.747 & $\mathrm{C} 8-\mathrm{C} 13$ & 1.397 \\
$\mathrm{C} 12-\mathrm{C} 11$ & 1.743 & $\mathrm{C} 8-\mathrm{C} 14$ & 1.507 \\
$\mathrm{~N} 1-\mathrm{C} 14$ & 1.476 & $\mathrm{C} 9-\mathrm{C} 10$ & 1.391 \\
$\mathrm{~N} 1-\mathrm{C} 7$ & 1.492 & $\mathrm{C} 10-\mathrm{C} 11$ & 1.385 \\
$\mathrm{~N} 1-\mathrm{C} 16$ & 1.498 & $\mathrm{C} 11-\mathrm{C} 12$ & 1.382 \\
$\mathrm{C} 1-\mathrm{C} 2$ & 1.374 & $\mathrm{C} 12-\mathrm{C} 13$ & 1.383 \\
$\mathrm{C} 1-\mathrm{C} 6$ & 1.384 & $\mathrm{C} 15-\mathrm{C} 16$ & 1.524 \\
$\mathrm{C} 2-\mathrm{C} 3$ & 1.398 & $\mathrm{C} 16-\mathrm{C} 18$ & 1.520 \\
$\mathrm{C} 3-\mathrm{C} 4$ & 1.382 & $\mathrm{C} 16-\mathrm{C} 17$ & 1.540 \\
\hline
\end{tabular}

\section{Spectroscopic analysis}

The computed absorption wavelengths at TD-B3LYP/6$31 \mathrm{G}^{* *}$ level of theory have been tabulated in Table 5 . Compound (1) showed four absorption peaks from 231 - $245 \mathrm{~nm}$ while compound (2) showed two absorption peaks at $214 \mathrm{~nm}$ and $245 \mathrm{~nm}$. Moreover, no significant effect of solvent polarity on the absorption wavelengths and oscillator strengths is observed in studied compounds. The synthesis of compounds (1) and (2) are also witnessed in their NMR spectra. All the hydrogen atoms of the oxazolidine ring system were non-equivalent, and therefore, a separate signal was observed for each proton. The hydrogen atom flanked by the $\mathrm{O}$ - and $\mathrm{N}$-atoms were most deshielded due to the inductive effect of two electron withdrawing groups and resonated in the range 
Table 3: Bond lengths for compound (2) in $(\AA)$

\begin{tabular}{lccc}
\hline Parameters & Bond lengths & Parameters & Bond lengths \\
\hline O3-C17 & 1.427 & C11-C12 & 1.377 \\
O3-C7 & 1.428 & C11-H11 & 0.930 \\
N1-C15 & 1.461 & C12-C13 & 1.384 \\
N1-C7 & 1.471 & C12-H12 & 0.930 \\
N1-C16 & 1.494 & C13-H13 & 0.930 \\
C1-C2 & 1.388 & C14-H14A & 0.960 \\
C1-C20 & 1.389 & C14-H14B & 0.960 \\
C1-H1 & 0.930 & C14-H14C & 0.960 \\
C2-C3 & 1.376 & C15-H15 & 0.983 \\
C2-H2 & 0.930 & C16-C18 & 1.514 \\
C3-C4 & 1.379 & C16-C17 & 1.520 \\
C3-H3 & 0.930 & C16-C19 & 1.520 \\
C4-C5 & 1.390 & C17-H17A & 0.970 \\
C4-H4 & 0.930 & C17-H17B & 0.970 \\
C5-C20 & 1.397 & C18-H18A & 0.960 \\
C5-C7 & 1.505 & C18-H18B & 0.960 \\
C6-H6A & 0.960 & C18-H18C & 0.960 \\
C6-H6B & 0.960 & C19-H19A & 0.970 \\
C6-H6C & 0.960 & C19-H19B & 0.970 \\
C7-H7 & 0.988 & & \\
\hline
\end{tabular}

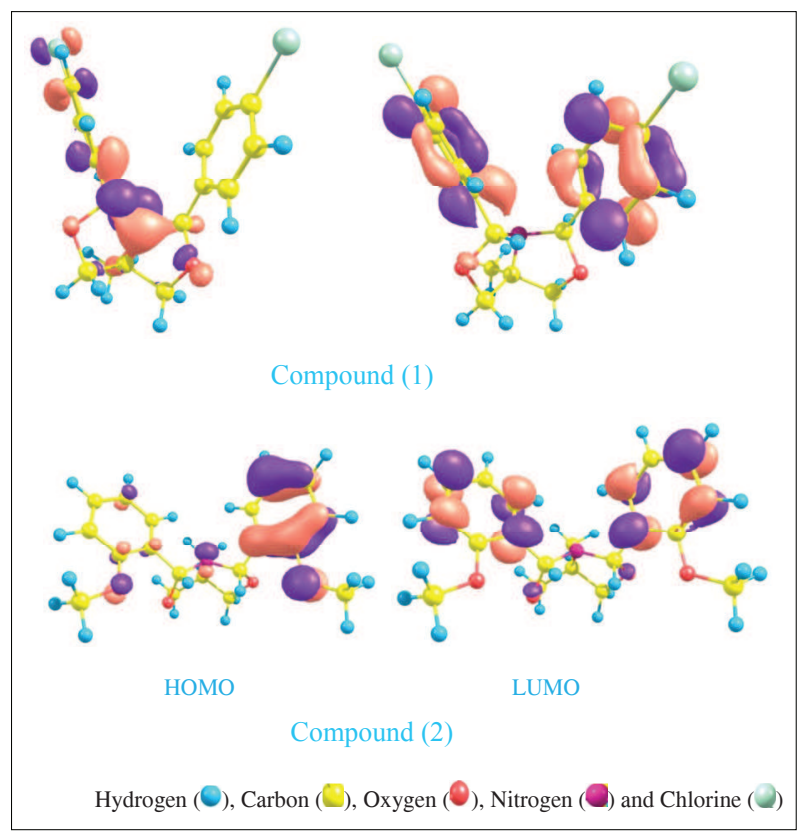

Figure 4: Representation of HOMOs and LUMOs density of studied compounds at B3LYP/6-31G** level of theory

Table 4: The experimental (Exp.) as well as ground states computed bond lengths ( $\AA$ ), bond angles (in degree) and torsion angles (in degree) at B3LYP/6-31G** level of theory

\begin{tabular}{|c|c|c|c|c|}
\hline & Opt & Exp. & Opt & Exp. \\
\hline & \multicolumn{2}{|c|}{ Compound (1) } & \multicolumn{2}{|c|}{ Compound (2) } \\
\hline & Bond lengths & & & \\
\hline $\mathrm{N} 1-\mathrm{C} 7$ & 1.485 & 1.492 & 1.466 & 1.461 \\
\hline $\mathrm{N} 1-\mathrm{C} 14$ & 1.475 & 1.476 & 1.486 & 1.471 \\
\hline $\mathrm{O} 1-\mathrm{C} 14$ & 1.429 & 1.432 & 1.425 & 1.428 \\
\hline $\mathrm{O} 1-\mathrm{C} 17$ & 1.421 & 1.429 & 1.420 & 1.427 \\
\hline $\mathrm{O} 2-\mathrm{C} 7$ & 1.422 & 1.424 & 1.442 & 1.440 \\
\hline $\mathrm{O} 2-\mathrm{C} 15$ & 1.419 & 1.423 & 1.419 & 1.424 \\
\hline $\mathrm{C} 4-\mathrm{C} 7$ & 1.514 & 1.507 & 1.524 & 1.510 \\
\hline $\mathrm{C} 8-\mathrm{C} 14$ & 1.512 & 1.506 & 1.514 & 1.505 \\
\hline $\mathrm{Cl} 1-\mathrm{C} 1$ & 1.760 & 1.747 & - & - \\
\hline \multirow[t]{2}{*}{$\mathrm{C} 12-\mathrm{C} 11$} & 1.759 & 1.742 & - & - \\
\hline & Bond angles & & & \\
\hline $\mathrm{C} 7-\mathrm{N} 1-\mathrm{C} 14$ & 117.36 & 117.40 & 114.11 & 114.77 \\
\hline $\mathrm{C} 14-\mathrm{O} 1-\mathrm{C} 17$ & 103.49 & 103.08 & 105.07 & 105.77 \\
\hline \multirow[t]{2}{*}{$\mathrm{C} 7-\mathrm{O} 2-\mathrm{C} 15$} & 105.26 & 103.88 & 104.98 & 104.36 \\
\hline & Torsion angles & & & \\
\hline $\mathrm{C} 4-\mathrm{C} 7-\mathrm{N} 1-\mathrm{C} 14$ & 103.98 & 102.95 & 137.25 & 133.48 \\
\hline \multirow[t]{3}{*}{$\mathrm{C} 4-\mathrm{C} 7-\mathrm{O} 2-\mathrm{C} 15$} & 160.87 & 161.69 & 88.84 & 89.44 \\
\hline & Dipole moments & & & \\
\hline & 4.11 & - & 1.57 & - \\
\hline
\end{tabular}


Table 5: The calculated HOMO energies ( $\left.\mathrm{E}_{\text {номо }}\right)$, LUMO energies $\left(\mathrm{E}_{\text {LUMO }}\right)$ and HOMO-LUMO energy gaps $\left(\mathrm{E}_{\text {gap }}\right)$ in $\mathrm{eV}$ of $\mathbf{1}^{\mathrm{a}}$ and $\mathbf{2}^{\mathrm{b}}$ at the B3LYP/6-31G**, absorption wavelengths $\left(\lambda_{\mathrm{a}}\right)$ $(\mathrm{nm})$ and oscillator strengths $(f)$ at TD-B3LYP/6-31G** level of theories in different solvents

\begin{tabular}{|c|c|c|c|c|}
\hline \multirow[t]{2}{*}{ Phase } & \multicolumn{2}{|c|}{ Compound (1) } & \multicolumn{2}{|c|}{ Compound (2) } \\
\hline & $f$ & $\lambda_{\mathrm{a}}$ & $f$ & $\lambda_{\mathrm{b}}$ \\
\hline \multirow[t]{4}{*}{ Gas phase } & 0.1213 & 213 & 0.0502 & 214 \\
\hline & 0.1083 & 221 & 0.0745 & 245 \\
\hline & 0.0122 & 237 & & \\
\hline & 0.0032 & 245 & & \\
\hline \multirow[t]{3}{*}{ Acetone } & 0.0778 & 223 & 0.0629 & 215 \\
\hline & 0.0179 & 238 & 0.0917 & 247 \\
\hline & 0.0068 & 251 & & \\
\hline \multirow[t]{3}{*}{ Acetonitrile } & 0.0782 & 224 & 0.0607 & 215 \\
\hline & 0.0176 & 238 & 0.0909 & 246 \\
\hline & 0.0067 & 251 & & \\
\hline \multirow[t]{3}{*}{ DMF } & 0.0829 & 224 & 0.0710 & 215 \\
\hline & 0.0186 & 238 & 0.0945 & 247 \\
\hline & 0.007 & 251 & & \\
\hline \multirow[t]{3}{*}{ DMSO } & 0.0824 & 224 & 0.0697 & 215 \\
\hline & 0.0184 & 238 & 0.0939 & 247 \\
\hline & 0.007 & 251 & & \\
\hline \multirow[t]{3}{*}{ Methanol } & 0.0772 & 224 & 0.0580 & 215 \\
\hline & 0.0174 & 238 & 0.0902 & 247 \\
\hline & 0.007 & 251 & & \\
\hline
\end{tabular}

${ }^{\text {a }} \mathrm{E}_{\text {номо }}, \mathrm{E}_{\text {LUмо }}$ and $\mathrm{E}_{\text {gap }}$ are $-6.44,-0.62$ and $5.82 \mathrm{eV}$, respectively.

${ }^{\mathrm{b}} \mathrm{E}_{\text {номо }}, \mathrm{E}_{\text {LUMO }}$ and $\mathrm{E}_{\text {gap }}$ are $-5.78,-0.0003$ and $5.78 \mathrm{eV}$, respectively.

of 5.6 to $5.0 \mathrm{ppm}$. The two protons in each methylene group are diastereotopic and appeared as doublets in the region from 4.1 to $3.6 \mathrm{ppm}$, a typical region for the protons of methylene units next to an oxygen atom. The aromatic protons in case of compound (1) resonated as four doublets each integrating to two protons, thus confirming the non-equivalence of two aromatic rings. However, two of the peaks were partially overlapping due to their comparable chemical shift values. In case of compound (2), the aromatic protons appeared as multiplets.

\section{CONCLUSION}

We report a facile synthetic route to synthesise two novel bicyclic oxazolidine compounds 3,5-bis(4-chlorophenyl)$7 \mathrm{a}$-methyldihydro-1 H-[1,3]oxazolo $[3,4-\mathrm{c}][1,3]$ oxazole (1) and 3,5-bis(2-methoxyphenyl)-7amethyldihydro-1H-[1,3] oxazolo [3,4-c][1,3] oxazole (2). The condensation reaction between 2-amino-2methyl-1,3-propandiol $\left(\mathrm{AmpdH}_{2}\right)$ and choloro- and methoxy-substituted aromatic aldehyde yielded bicyclic oxazolidines (1) and (2), respectively. These compounds were characterised using spectroscopic techniques as well as single crystal X-ray diffraction analysis. The B3LYP/6$31 \mathrm{G}^{* *}$ level of theory is a good choice to reproduce the experimental geometrical parameters. Intra-molecular charge transfer was observed in synthesised compounds. Moreover, no significant variation is observed on the absorption wavelengths by changing the solvent. The methoxy groups increased the energies of the highest occupied and unoccupied molecular orbitals.

\section{Acknowledgement}

Authors would like to acknowledge the support of the Research Center for Advanced Materials Science, King Khalid University, Kingdom of Saudi Arabia for this research through a grant RCAMS/KKU/005-18.

\section{Supplementary material}

CCDC 936163 contains the supplementary crystallographic data of compounds of this article. The data can be obtained free of charge via http://www.ccdc. cam.ac.uk/conts/retrieving.html or from the Cambridge Crystallographic Data Centre, 12 Union Road, Cambridge CB2 IEZ UK. Supplementary information associated with this article can be found in the online version.

\section{REFERENCES}

1. Abbas G., Kostakis G.E., Lan Y. \& Powell A.K. (2012). Synthesis and characterization of isostructural tetranuclear lanthanide complexes $\left[\operatorname{Ln}_{4}(\mu 3-\right.$ $\left.\mathrm{OH})_{2}\left(\mathrm{ampdH}_{4}\right)_{2}(\mathrm{piv})_{10}\right] \cdot 4 \mathrm{CH}_{3} \mathrm{CN}(\mathrm{Ln}=\mathrm{Sm}, \mathrm{Eu}, \mathrm{Gd}, \mathrm{Tb}, \mathrm{Dy}$, Ho, Er). Polyhedron 41(1): $1-6$.

DOI: https://doi.org/10.1016/j.poly.2012.03.022

2. Altomare A., Cascarano G., Giacovazzo C., Guagliardi A., Burla M.C., Polidori G. \& Camalli M. (1994). SIR92 - a program for automatic solution of crystal structures by direct methods. Journal of Applied Crystallography 27(3): 435.

DOI: https://doi.org/10.1107/S002188989400021X

3. Becke A.D. (1993). Density-functional thermochemistry. III. The role of exact exchange. The Journal of Chemical Physics 98(7): 5648 - 5652.

DOI: https://doi.org/10.1063/1.464913

4. Bergmann E.D. (1953). The oxazolidines. Chemical Reviews 53(2): 309 - 352.

DOI: https://doi.org/10.1021/cr60165a005 
5. Crabb T.A., Hall M.J. \& Williams R.O. (1973). Proton magnetic resonance studies of compounds with bridgehead nitrogen atoms-XXVI. Tetrahedron 29(21): 3389 - 3398.

6. Frisch M.J. et al. (74 authors) (2016). Gaussian-16, Revision A.1, Gaussian, Inc., Wallingford, CT.

7. Gruhn N.E., da Silva Filho D.A., Bill T.G., Malagoli M., Coropceanu V., Kahn A. \& Brédas J.-L. (2002). The vibrational reorganization energy in pentacene: molecular influences on charge transport. Journal of the American Chemical Society 124(27): 7918 - 7919.

DOI: https://doi.org/10.1021/ja0175892

8. Huguenot F. \& Brigaud T. (2006). Convenient asymmetric synthesis of $\beta$-Trifluoromethyl- $\beta$-amino acid, $\beta$-Amino ketones, and $\gamma$-Amino alcohols via reformatsky and mannich-type reactions from 2-Trifluoromethyl-1,3oxazolidines. The Journal of Organic Chemistry 71(5): $2159-2162$

DOI: https://doi.org/10.1021/jo052323p

9. Irfan A. (2013). Quantum chemical investigations of electron injection in triphenylamine-dye sensitized $\mathrm{TiO}_{2}$ used in dye sensitized solar cells. Materials Chemistry and Physics 142(1): 238 - 247.

DOI: https://doi.org/10.1016/j.matchemphys.2013.07.011

10. Irfan A. (2014). Modeling of efficient charge transfer materials of 4,6-di(thiophen-2-yl)pyrimidine derivatives: quantum chemical investigations. Computational Materials Science 81(0): 488 - 492.

DOI: https://doi.org/10.1016/j.commatsci.2013.09.003

11. Irfan A., Al-Sehemi A.G., Chaudhry A.R. \& Muhammad S. (2017a). First principles study of the n-channel thiophene based heterocyclic chalcones. Optik - International Journal for Light and Electron Optics 138: 349 - 358.

12. Irfan A., Al-Sehemi A.G., Chaudhry A.R., Muhammad S. \& Asiri A.M. (2016). The structural, electro-optical, charge transport and nonlinear optical properties of 2-[(3,5-dimethyl-1-phenyl-1H-pyrazol-4-yl)methylidene] indan-1,3-dione. Optik - International Journal for Light and Electron Optics 127(21): 10148 - 10157.

13. Irfan A., Kalam A., Chaudhry A.R., Al-Sehemi A.G. \& Muhammad S. (2017b). Electro-optical, nonlinear and charge transfer properties of naphthalene based compounds: a dual approach study. Optik - International Journal for Light and Electron Optics 132: $101-110$.

14. Kang Y.-f., Wang R., Liu L., Da C.-s., Yan W.-j. \& Xu Z.-q. (2005). Enantioselective alkynylation of aromatic aldehydes catalyzed by new chiral oxazolidine ligands. Tetrahedron Letters 46(5): 863 - 865.

DOI: https://doi.org/10.1016/j.tetlet.2004.11.165

15. Kim S.-G., Kim K.-H., Kim Y.K., Shin S.K. \& Ahn K.H. (2003). Crucial role of three-center hydrogen bonding in a challenging chiral molecular recognition. Journal of the American Chemical Society 125(45): 13819 - 13824.
DOI: https://doi.org/10.1021/ja037031p

16. Lee C., Yang W. \& Parr R.G. (1988). Development of the Colle-Salvetti correlation-energy formula into a functional of the electron density. Physical Review B 37(2): 785 - 789. DOI: https://doi.org/10.1103/PhysRevB.37.785

17. Martins M.A.P., Frizzo C.P., Moreira D.N., Buriol L. \& Machado P. (2009). Solvent-free heterocyclic synthesis. Chemical Reviews 109(9): 4140 - 4182.

DOI: https://doi.org/10.1021/cr9001098

18. Martins M.A.P., Frizzo C.P., Moreira D.N., Zanatta N. \& Bonacorso H.G. (2008). Ionic liquids in heterocyclic synthesis. Chemical Reviews 108(6): 2015 - 2050. DOI: https://doi.org/10.1021/cr078399y

19. Matthews D., Infelta P. \& Gratzel M. (1996). Calculation of the photocurrent-potential characteristic for regenerative, sensitized semiconductor electrodes. Solar Energy Materials and Solar Cells 44(2): 119 - 155.

20. Miehlich B., Savin A., Stoll H. \& Preuss H. (1989). Results Obtained with the correlation energy density functionals of Becke and Lee, Yang and Parr. Chemical Physics Letters 157(3): 200 - 206.

21. Peera A.A. \& TomLinson I.A. (2015). Formation of heterocyclic and polycyclic compounds from amino alcohols and dialdehydes. Journal of Heterocyclic Chemistry 52(2): $603-606$.

DOI: https://doi.org/10.1002/jhet.2080

22. Petersson G.A., Bennett A., Tensfeldt T.G., Al-Laham M.A. \& Shirley W.A. (1988). A complete basis set model chemistry. I. The total energies of closed-shell atoms and hydrides of the first-row elements. The Journal of Chemical Physics 89(4): 2193 - 2218.

DOI: https://doi.org/10.1063/1.455064

23. Saiz C., Wipf P. \& Mahler G. (2011). Synthesis and ring-chain-ring tautomerism of bisoxazolidines, thiazolidinyloxazolidines, and spirothiazolidines. The Journal of Organic Chemistry 76(14): 5738 - 5746. DOI: https://doi.org/10.1021/jo2008498

24. Sánchez-Carrera R.S., Coropceanu V., da Silva Filho D.A., Friedlein R., Osikowicz W., Murdey R., Suess C., Salaneck W.R. \& Brédas J.-L. (2006). Vibronic coupling in the ground and excited states of oligoacene cations. The Journal of Physical Chemistry B 110(38): 18904 - 18911. DOI: https://doi.org/10.1021/jp057462p

25. Sheldrick G.M. (1997). SHELXS97 and SHELXL97. Program for Crystal Structure Solution and Refinement. University of Göttingen, Göttingen.

26. Sriharsha S.N. \& Shashikanth S. (2006). Synthesis and antimicrobial activity of novel 1,3-oxazolidine nucleoside analogues. Heterocyclic Communications 12: 213 - 218. DOI: https://doi.org/10.1515/HC.2006.12.3-4.213

27. Swedo R. \& Green G. (2004). Novel Phenolic Resins. US Patent 20050054787. 